Article

\title{
Biogas, Biomethane and Digestate Potential of By-Products from Green Biorefinery Systems
}

\author{
Rajeev Ravindran ${ }^{1}$, Kwame Donkor ${ }^{2}$, Lalitha Gottumukkala ${ }^{2}$, Abhay Menon ${ }^{1}$, Amita Jacob Guneratnam ${ }^{1}$, \\ Helena McMahon ${ }^{1}$, Sybrandus Koopmans ${ }^{3}$, Johan P. M. Sanders ${ }^{3,4}$ and James Gaffey ${ }^{1, *}$
}

1 Circular Bioeconomy Research Group, Shannon Applied Biotechnology Centre, Munster Technology, V92 CX88 Tralee, Ireland; rajeev.ravindran@mtu.ie (R.R.); abhay.menon@mtu.ie (A.M.); amita.Guneratnam@mtu.ie (A.J.G.); helena.mcmahon@mtu.ie (H.M.)

2 Celignis Limited, Unit 11 Holland Road, Plassey Technology Park, Castletroy, Co., V94 7Y42 Limerick, Ireland; kwame.celignis@outlook.com (K.D.); lalitha@celignis.com (L.G.)

3 Grassa BV, Campus Building Villa Flora, Box 72, Villafloraweg 1, 5928 SZ Venlo, The Netherlands; bram@grassa.nl (S.K.); johan@grassa.nl (J.P.M.S.)

4 Biobased Chemistry and Technology, Wageningen University and Research, Bornse Weildanden 9, 6708 WG Wageningen, The Netherlands

* Correspondence: james.gaffey@mtu.ie; Tel.: +353-667144253

check for

updates

Citation: Ravindran, R.; Donkor, K.; Gottumukkala, L.; Menon, A.; Guneratnam, A.J.; McMahon, H.; Koopmans, S.; Sanders, J.P.M.; Gaffey, J. Biogas, Biomethane and Digestate Potential of By-Products from Green Biorefinery Systems. Clean Technol. 2022, 4, 35-50. https://doi.org/ 10.3390/cleantechnol4010003

Academic Editor: Patricia Luis

Received: 13 November 2021

Accepted: 6 January 2022

Published: 17 January 2022

Publisher's Note: MDPI stays neutral with regard to jurisdictional claims in published maps and institutional affiliations.

Copyright: (c) 2022 by the authors. Licensee MDPI, Basel, Switzerland. This article is an open access article distributed under the terms and conditions of the Creative Commons Attribution (CC BY) license (https:/ / creativecommons.org/licenses/by/ $4.0 /)$.

\begin{abstract}
Global warming and climate change are imminent threats to the future of humankind. A shift from the current reliance on fossil fuels to renewable energy is key to mitigating the impacts of climate change. Biological raw materials and residues can play a key role in this transition through technologies such as anaerobic digestion. However, biological raw materials must also meet other existing food, feed and material needs. Green biorefinery is an innovative concept in which green biomass, such as grass, is processed to obtain a variety of protein products, value-added co-products and renewable energy, helping to meet many needs from a single source. In this study, an analysis has been conducted to understand the renewable energy potential of green biorefinery by-products and residues, including grass whey, de-FOS whey and press cake. Using anaerobic digestion, the biogas and biomethane potential of these samples have been analyzed. An analysis of the fertiliser potential of the resulting digestate by-products has also been undertaken. All the feedstocks tested were found to be suitable for biogas production with grass whey, the most suitable candidate with a biogas and biomethane production yield of 895.8 and $544.6 \mathrm{~L} / \mathrm{kg} \mathrm{VS}$, respectively, followed by de-FOS whey and press cake (597.4/520.3 L/ kg VS and 510.7/300.3 L/kg VS, respectively). The results show considerable potential for utilizing biorefinery by-products as a source for renewable energy production, even after several value-added products have been co-produced.
\end{abstract}

Keywords: green biorefinery; grass whey; anaerobic digestion; biogas; digestate

\section{Introduction}

Climate change and interrelated environmental challenges represent the most eminent issues that threaten the future of the humankind. The European Commission launched 'The Green New Deal' in 2019, with aims to make Europe carbon neutral by 2050. As part of the deal, the EU has attributed more importance towards biodiversity, farming, energy and circular economy [1]. However, the energy sector is responsible for 75\% of the total greenhouse emissions in the EU. Ensuring a greater contribution of renewable sources of energy across all sectors has been identified as a key building block for achieving climate and energy objectives. The Renewable Energy Directive (2009/28/EC) is a legal framework supporting renewable energy integration across all sectors in the EU [2]. This directive set out an overall target of $20 \%$ renewable energy integration by 2020 , with binding contributory targets for each of the individual states. However, Ireland failed to meet its 2020 Renewable Energy Directive Target of 16\%, falling short particularly in 
areas of renewable heat and transport. As a result, Ireland now faces a tougher task of meeting its updated Renewable Energy Directive II (RED II) target of 32\% by 2030 [3]. Furthermore, Ireland's Climate Action Bill requires a 51\% reduction in GHG by 2030, rising to carbon neutrality by 2050 . On the other hand, the agri-food sector is a vibrant industry in Ireland whose contribution to GDP has increased from $17.8 \%$ to $19.9 \%$ between $2019-2020$ and 2020-2021 [4]. However, 30\% of greenhouses emissions in Ireland are contributed by agricultural activities [5]. A recent report published by the Environmental Protection Agency in Ireland reported that methane levels in Ireland had increased by over $170 \%$ from the pre-industrial era, largely due to the livestock industry [6]. This calls for immediate and effective measures to reduce the environmental footprint of the Irish agriculture sector.

Biogas production has been identified as a potential step for the reduction in carbon emissions from primary production (e.g., livestock emissions and slurry related emissions) in recent years [7]. Biogas or biomethane is a renewable source of energy that can also directly reduce fossil-based emissions in sectors such as transport, heat and electricity, thus contributing to climate mitigation and renewable energy targets [8]. According to a survey conducted by the Central Statistics Office, Ireland, 3.7 million out of a total of 5 million hectares of agricultural land in Ireland, were grassland with 450,300 hectares attributed to rough grazing [9]. Grass silage has been explored as a potential source for anaerobic digestion [10-12]. However, operating an anaerobic digestion (AD) process following the mono-digestion of grass silage has been found to be unsustainable in the long term [13]. Interestingly, the co-digestion of silage with animal manures and slurries have been found to be a better alternative by comparison. According to a recent study published by Attard et al. (2020), more than 30 million tonnes of (wet weight) biomass were generated in Ireland in 2020, including 27 million tonnes of slurries and manures, while 1.7 million tonnes of dry matter (DM) of grassland is available annually beyond that are required to meet our food targets [14,15]. This 1.7 million could be increased to 12 million tonnes through the adoption of specific land management practices [15]. Several studies have investigated the co-digestion of grass and slurry. For example, Xie (2012) reported that maintaining pig manure and grass silage at a ratio of 3:1 yielded $304.2 \mathrm{~mL} \mathrm{CH}_{4} / \mathrm{g} \mathrm{ml}$ when the two biomass sources were co-digested [16]. In another study, Himanshu et al. (2019) reported that maximum synergistic effects for biogas production can be achieved by maintaining a feed ratio of 0.75:0.25 for perennial ryegrass silages with cattle slurry [17]. Both studies observed that increasing the proportion of silage in the feedstock mixture progressively decreased the cost of methane production, increased the methane yield and increased overall plant profitability. A recent study conducted by Beausang et al. (2021) employed a consequential life cycle assessment to assess the environmental impacts of digesting different proportions of silage and cattle slurry for biogas production [18]. The study observed higher environmental burdens on the mixes with a greater ratio of grass silage to slurry with an optimum environmental performance observed at a VS ratio of 0.4:0.6 for silage and slurry, where there is a net reduction for all impact categories considered.

Ireland stands to gain from the large areas of grasslands and volumes of manure and slurries produced if these feedstocks can be effectively exploited for the production of biogas and biomethane via anaerobic digestion. The findings of Gas Networks Ireland claim that Ireland has the highest potential for biogas/biomethane production per capita in Europe, with a potential to achieve 13 TWh of energy via renewable gas by 2030. The agency has therefore put in motion a strategic plan to achieve $20 \%$ of renewable gas integrated within its network by 2030 [19]. Another interesting report published by KPMG suggested that replacing natural gas with biogas obtained using ADcan reduce carbon emissions by 93\% [20]. Separately, O'Connor et al. (2021) examined the adoption of anaerobic digestion for energy production in Irish farms [21]. The study was conducted among cattle farmers to understand their motivations, perceived barriers and preferred business models. The study found that $41 \%$ of the farmers surveyed were supportive of installing an AD system on their farms. Lack of information regarding the technology and investment costs were 
identified as the bottlenecks for AD installation on farms. Furthermore, approx. $60 \%$ of farmers were interested in adopting a co-operative business scheme to install and operate anaerobic digestors in their farms.

As we shift from a fossil-based to a bio-based economy, there is an increasing demand on our biological resources to meet our global food, feed and traditional material products, as well as energy requirements, while also providing an array of new products such as novel protein, bioplastics, chemicals and biofuels. A biorefinery can support more efficient use of biological resources, through co-processing into a range of bio-based products and energy. A green biorefinery is a sustainable process for exploiting green protein-rich biomass to produce a spectrum of commercially valuable products and energy. The feedstock for a green biorefinery can include any naturally occurring green biomass, such as grass, clover, sugar beet leaves, vegetable leaves etc. These plants and residues are rich in a wide variety of biomolecules, such as carbohydrates, lignin, proteins, lipids, polyphenols, andvitamins. The green biorefinery concept is at a relatively advanced stage in Western Europe, especially in countries such as Germany, Netherlands, Switzerland, Denmark and Austria [22]. Commercial green biorefinery enterprises have been developed by industry players, such as Biowert, Gramitherm and Newfoss, to produce plant-based products, such as technical fibers for composites, insulation materials, plastics and paper. At the same time, residual streams from the biorefinery process can be used to produce energy for the process, helping to improve the sustainability of the biorefinery. The Biowert Green Biorefinery cycle involves processing of grass silage to produce grass fibers, which are further converted into synthetic granules and biocomposite materials. The liquid that is a by-product of the biorefining process is used to produce biogas. The energy obtained from the $\mathrm{AD}$ process is sufficient enough to operate the biorefining process, while the digestate obtained after anaerobic digestion is further concentrated and converted into fertilizer, which is marketed to farmers completing the nutrient cycle [23]. Meanwhile, biorefineries that process grass feedstocks into plant protein feed and food products, as well as bioenergy, have also been developed by Aarhus University in Denmark and GRASSA B.V. in the Netherlands [24]. These approaches demonstrate the potential to use grass components to produce biogas through anaerobic digestion but follow a cascading biorefinery approach, which ensures the co-production of additional value-added co-products such as feed proteins and prebiotic ingredients. In addition to helping to meet Irelands renewable energy and climate obligations, such cascading approaches may also support the broader sustainability commitments of the United Nations' Sustainable Development Goals, helping to meet SDG7 (affordable and clean energy) by delivering a more economically viable co-processing approach, which balances the production of renewable energy, with higher value materials and proteins that are essential for animal and human consumption. Fonseca et al. (2020), highlights that SDG7 has significant relationships with other SDGs, including SDG1 (no poverty), SDG2 (zero hunger), SDG3 (good health and well-being), SDG8 (decent work and economic growth) and SDG13 (climate action) [25]. There, the wider impact of clean energy approaches, taking into account other pillars of sustainable living, is a key consideration.

A previous study on green biorefineries has been conducted in Denmark, where researchers evaluated a biorefinery process that utilised red clover, clover grass, alfalfa and oilseed radish as feedstocks for the extraction of protein for monogastric feed applications and subsequent conversion of press cake and grass juice into biogas and fertilizer [26]. The press cake and the brown juice were subjected to mono-digestion and co-digestion strategies. The study revealed that the co-digestion strategy was the preferred method for biogas production, considering ease in process control. Other work from Feng et al. (2021) explored the pilot-scale anaerobic digestion of by-product liquid (brown juice) from grass protein extraction using an un-heated anaerobic filter [27]. Using a different greenbiorefinery approach, Patterson et al. (2020) investigated the extraction of volatile fatty acids from grass and subsequent production of polyhydroxyalkanoates. In this case part of the unrefined grass was used for anaerobic digestion to produce biomethane [28]. 
Fernandez de Souza et al. (2020) explored the use of extrusion to pre-treat fresh grass and grass silage prior to anaerobic digesting and indicate enhanced biomethane yields of biogas of $18 \%$ and $11 \%$ respectively on a fresh matter basis [29]. The main objective of the current study was to assess the biogas and biomethane production potential of three biorefinery output streams that were generated as a result of a novel grass biorefining process. The current study presents and analyzes research of the Irish Biorefinery Glas green biorefinery project [30]. Perennial rye grass was used as a feedstock for the green biorefinery which enabled the extraction of grass protein concentrate and dietary fiber in the form of fructooligosaccharides (FOS). The residual streams of grass whey and de-FOS whey, in addition to a press cake co-product (otherwise used for feeding cows), were studied to understand their biogas potential. Finally, the digestate obtained from the different biogas production trials was also investigated as to understand the potential fertilizer value. While previous work has been undertaken in Ireland to assess the biomethane potential of unrefined perennial ryegrass [31-33], and some international studies have been conducted which analyze or estimate the biomethane potential of green biorefinery co-products [26,34], the authors could not find any Irish studies which have assessed the biogas or biomethane potential of green biorefinery co-products. In addition, the authors did not find any similar study in which the focus of research was a similar biorefinery sidestream (press cake, whey and de-FOS whey) resulting from the biorefinery of the feedstock perennial rye grass. Finally, the production of FOS is a novel aspect of the green biorefinery process used, so the application of de-FOS whey as a substrate for biogas production is assessed for the first time.

\section{Materials and Methods}

\subsection{Green Biorefinery Residual Co-Products (Grass Press Cake, Grass Whey and De-FOS Whey) Preparation}

Perennial rye grass (Lolium perenne) obtained from a farm located in West Cork, Republic of Ireland was utilized for input into a novel green biorefinery developed by GRASSA B.V. A schematic of the process is presented in Figure 1. The fresh grass was washed and then subjected to an extrusion process to obtain a high dry matter press cake fraction and a high protein juice fraction. The grass juice was then filtered and subjected to heat treatment at $80^{\circ} \mathrm{C}$, followed by centrifugation to remove the precipitated protein. The residual liquid fraction (whey) following the protein extraction was further processed to extract FOS, leaving a residual stream (de-FOS whey). The production of FOS is a unique feature of the biorefinery process, not included within similar fresh green biorefinery approaches described in the literature [34,35]. The press cake fraction, whey and de-FOS whey were analyzed for total solids, volatile solids, elemental analysis and fiber composition. All potential feedstocks were stored at $4{ }^{\circ} \mathrm{C}$ until further analysis. All analyses were completed within two weeks of the extraction process.

\subsection{Biomethane Potential (BMP) Assays}

All three assessed green biorefinery co-products (grass press cake, grass whey and deFOS whey), in addition to unrefined ryegrass silage, were investigated for their biomethane potential (BMP). Unrefined ryegrass silage was included within the analysis for comparative purposes. The BMPs of the green biorefinery residual co-products were determined by employing an Anaero BMP system and followed protocols outlined in the German standard method VDI 4630. The BMP system consists of 15 plastic bottle digesters, each with a volume of one liter. BMP tests were performed with active inoculum maintained in the lab by feeding mixed waste streams (food waste, grass silage and whey permeate). The inoculum was sieved and degassed to avoid interference of organic matter present in the inoculum with the test sample. The volume to headspace ratio of the digester is 7:3, and the inoculum to substrate ratio is $4: 1$ for the BMP analysis. The $\mathrm{pH}$ of each digester was within the optimum anaerobic digestion range; hence, a $\mathrm{pH}$ adjustment with special reagents or buffers was not done in these BMP tests. All digesters were mixed at the same speed 
using stainless steel paddle systems that guaranteed even mixing for all substrate-inoculum mixtures. The temperature of each digester was maintained at $37^{\circ} \mathrm{C}$ with a water bath that incorporates a tight-fitting cover, which minimizes bathwater evaporation loss, even at thermophilic temperatures. All experiments were conducted in triplicates and lasted for 21 days of digestion.

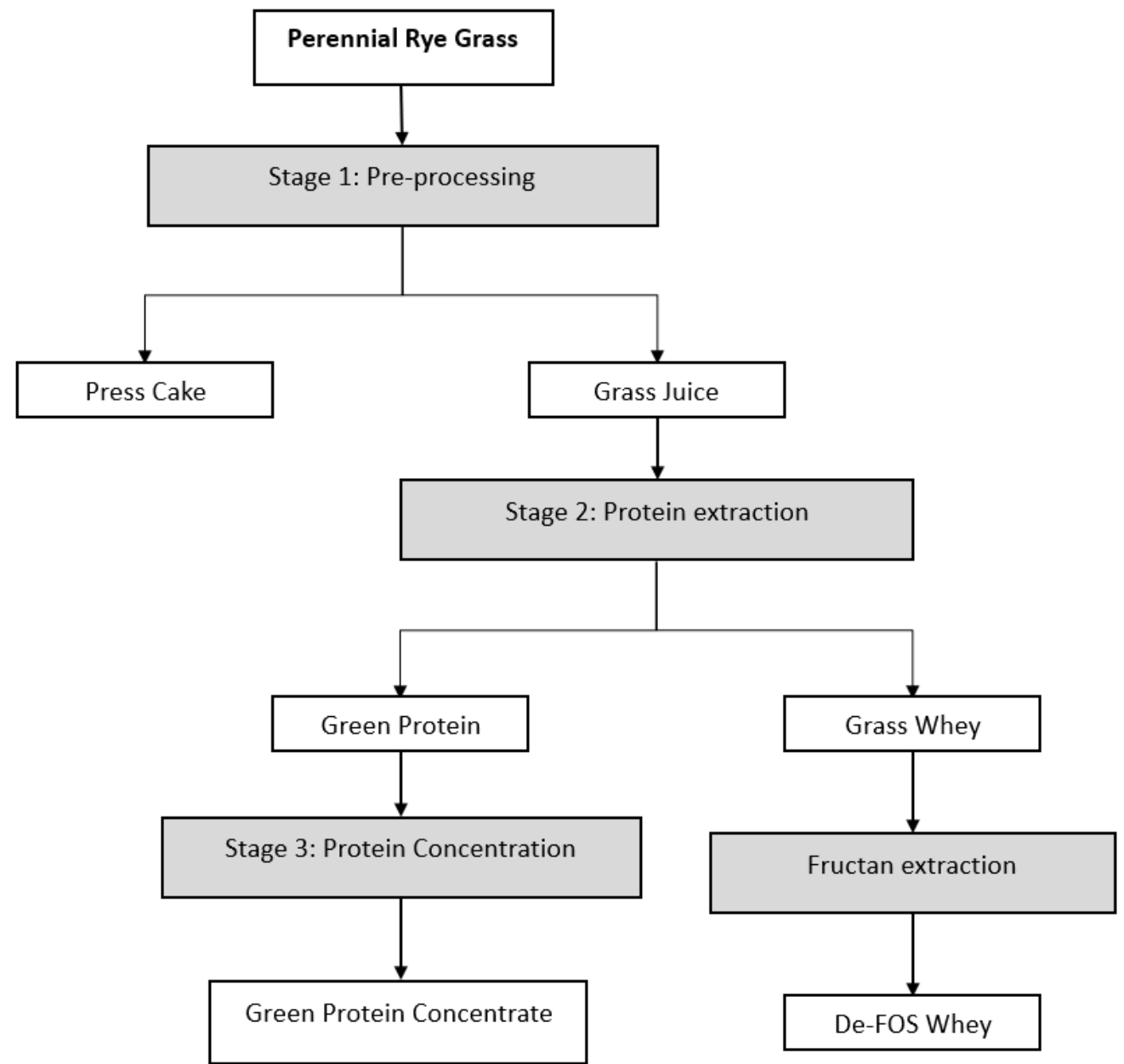

Figure 1. Schematic of green biorefinery process.

\subsection{Compositional Analysis of Press Cake}

Composition of the biorefinery press cake was analyzed by following the Laboratory Analytical Procedure (LAP), published by the National Renewable Energy Laboratory (NREL) [36]. In brief, the press cake was dried in the oven at $70{ }^{\circ} \mathrm{C}$ and milled to $0.2 \mathrm{um}$ size using a Retsch Ultra Centrifugal Mill ZM 200. The milled sample was subjected to water extraction, followed by ethanol extraction (95\% ethanol) at $100{ }^{\circ} \mathrm{C}$ and 1500 PSI using a Dionex accelerated solvent extraction system (ASE). The extractives obtained are classified as water, ethanol and full extractives (water followed by ethanol). The extracted solid residue is dried at $40{ }^{\circ} \mathrm{C}$ and hydrolyzed by two-step acid hydrolysis method. The hydrolysate is filtered through a medium-size filtering crucible, and the solid residue retained on the filter was kept for moisture and ash analysis to determine the acid insoluble residue and Klason lignin, respectively. Acid-soluble lignin in the filtrate is measured by recording the absorbance of liquid at $240 \mathrm{~nm}$ and applying the equation provided in the NREL LAP method. The sugars released by acid hydrolysis were analyzed by Ion chromatography with a PA1 column and melibiose as the internal standard. 


\subsection{Analytical and Chemical Methods}

\subsubsection{Chemical Characterization of Biorefinery Co-Product Substrates and Digestate}

The analytical and chemical methods used for the characterization of the various biorefinery residual co-products followed protocols outlined in the European standards reference methods indicated in Table 1 . All these analytical methods were also applied to corresponding digestates after biomethane potential tests. Proximate analysis (total solids, volatile solids, moisture and ash contents) of the substrates and corresponding digestates were measured according to the European standards outlined in the reference methods EN 14774-1:2009 and EN 14775:2009. The carbon, hydrogen, nitrogen and oxygen were analyzed with a vario MARCO cube elemental analyzer that used a thermal conductivity detector (TCD) and an optional infrared detector to determine the sulfur content of the substrates. The chemical oxygen demand (COD) estimates the amount of oxygen needed by organic matter present in the sample to be oxidized by a strong chemical oxidant. The COD was analyzed by first using a Hanna Instruments heating reactor (HI 839800 Reactor) at $150{ }^{\circ} \mathrm{C}$ for $2 \mathrm{~h}$ to digest the COD reagent kit (HI93754C-0) containing a $200 \mathrm{mg}$ sample, and, afterward, a Hanna Instruments multiparameter photometer (HI 83399) was used to determine the COD the digested COD tubes. The Hanna Instruments multiparameter photometer utilized for the COD analysis was also used to determine the ammonia content of the various substrates. However, this protocol used an ammonia high range reagent kit (H193733-01) and does not involve a 2-h digestion step as outlined in the COD method. The biological oxygen demand (BOD) determines the amount of oxidizable organic matter by microorganisms in a unit value of the substrate. Approximately $1 \mathrm{~g}$ of the sample, together with a Hach BOD nutrient buffer (APHA formulation), were placed in an airtight BOD serum bottle for five days at $20{ }^{\circ} \mathrm{C}$. Readings were measured on the first and last day of the test with the Hanna Instruments conductivity meter (H1764080) and used to determine the BOD of the substrates. An Agilent ICP-OES 5110 with an axial view configuration spectrometer and Seaspray flow nebulizer was used to analyze for major and minor elements in digested substrates. Sample digestion was achieved in a "MARS 6 Microwave Reaction System" at $190^{\circ} \mathrm{C}$ for $65 \mathrm{~min}$ and followed protocols outlined in reference method US EPA 3050. Furthermore, certified reference sample $1570 \mathrm{~A}$ in the form of spinach was also digested along with the biorefinery co-product samples to validate the quality of a subsequent ICP analysis.

Table 1. Feedstock analysis for biorefinery products.

\begin{tabular}{|c|c|c|c|c|c|}
\hline Analysis & Reference Method & Units & Grass Press Cake & Grass Whey \# & De-FOS Whey \\
\hline Moisture & EN 14774-1:2009 (STANDARD, 2010) & $\%$ & $61.00 *$ & $97.97 *$ & $91.33 *$ \\
\hline Total Solids & Calculated & $\%$ & $39.00 *$ & $2.03 *$ & $8.67 *$ \\
\hline Ash & EN 14775:2009 (Standard, 2009) & $\%$ & 4.67 & 20.99 & 19.94 \\
\hline Volatile Solids & Calculated & $\%$ & 95.33 & 79.01 & 80.06 \\
\hline NPK & & & 14:1:7.5 & 2.9:1:11.8 & 4.3:1:7.3 \\
\hline Carbon & EN 15104:2011 (EN, 2011 b) (ISO/TC 238, 2015 a) & $\%$ & 47.81 & 37.73 & 40.70 \\
\hline Hydrogen & EN 15104:2011 & $\%$ & 5.73 & 5.09 & 4.76 \\
\hline Nitrogen & EN 15104:2011 & $\%$ & 2.74 & 2.18 & 4.34 \\
\hline Sulphur & EN 15289:2011(ISO/TC 238, 2015 a) & $\%$ & 0.22 & 0.37 & 0.35 \\
\hline Oxygen & By Difference & $\%$ & 38.84 & 33.64 & 29.90 \\
\hline Aluminium & EN ISO 16967:2015 (EN, 2011 a) & $\mathrm{ppm}$ & $224(87) *$ & & $313(27) *$ \\
\hline Calcium & EN ISO 16967:2015 & $\mathrm{ppm}$ & $4254(1659) *$ & & $7977(692) *$ \\
\hline Iron & EN ISO 16967:2015 & $\mathrm{ppm}$ & $413(161)^{*}$ & & $387(34)^{*}$ \\
\hline Magnesium & EN ISO 16967:2015 & $\mathrm{ppm}$ & $1100(429) *$ & & $4973(431) *$ \\
\hline Sodium & EN ISO 16967:2015 & $\mathrm{ppm}$ & $2379(928) *$ & & $2750(238) *$ \\
\hline Phosphorus & EN ISO 16967:2015 & $\mathrm{ppm}$ & $1960(764) *$ & 7434 & $10063(872) *$ \\
\hline Potassium & EN ISO 16967:2015 & $\mathrm{ppm}$ & $15159(5912) *$ & 87057 & $72877(6318) *$ \\
\hline Silicon & EN ISO 16967:2015 & ppm & $2434(949)^{*}$ & & $1821(158)^{*}$ \\
\hline Titanium & EN ISO 16967:2015 & $\mathrm{ppm}$ & $12(5)$ * & & $11(1) *$ \\
\hline COD & Modified EPA 410.4 (O'Dell, 1993) & $\mathrm{g} / \mathrm{kg}$ & 1143 & 968 & 984 \\
\hline BOD & In-House & $\mathrm{g} / \mathrm{kg}$ & 924 & 798 & 837 \\
\hline Ammonia & In-House & $\mathrm{g} / \mathrm{kg}$ & $1.54 *$ & 170 & $1.62 *$ \\
\hline
\end{tabular}

\# Proximate analysis was reported for 2-fold dilution of grass whey with washing water. Note: * values reported on as-received basis. All other values are reported on dry mass basis. 


\subsubsection{Biogas Production Potential}

The biogas production from each digester was measured continuously by the flow meter provided with the Anaero system, and the gas was collected in 2 L Tedlar bags. The flow meter was composed of 15 chambers (each with a buoyancy bucket design) filled with a salt solution that did not allow the dissolution of carbon dioxide, hydrogen sulphide or ammonia content of the produced biogas. The gas volume is corrected for temperature and pressure to obtain normalized biogas volumes. The biogas collected in the Tedlar bags was analyzed for composition using a Biogas 5000 gas analyzer equipped with methane, carbon dioxide, hydrogen sulphide, ammonia and oxygen sensors. The gas composition analysis was done on the $3 \mathrm{rd}, 7 \mathrm{th}, 14 \mathrm{th}$ and 21 st days of the BMP analysis. The biogas and biomethane yields for biorefinery feedstock were determined using equations provided below:

$$
\text { Cumulative biogas produced }=\sum_{\text {Day0 }}^{\text {Day21 }}(\text { biogas produced per day }(\mathrm{mL}))
$$

Ref. [37]

$$
\text { Biogas yield }=\frac{\text { Cumulative biogas produced }(\mathrm{mL})}{\text { FM or TS or VS fed }(\mathrm{g})}
$$

Ref. [38]

Average $\mathrm{CH}_{4}$ percentage $=$ Determined from Biogas analyzer 5000

Ref. [39]

Cumulative $\mathrm{CH}_{4}$ produced $=\sum_{\text {Day0 }}^{\text {Day21 }}\left(\%\right.$ Average $\mathrm{CH}_{4} \times$ biogas produced per day $\left.(\mathrm{mL})\right)$

Ref. [40]

$$
\text { Methane yield }=\frac{\text { Cumulative methane produced }(\mathrm{L})}{\text { FM or TS or VS fed }(\mathrm{kg})}
$$

Ref. [41]

$$
\begin{aligned}
\text { Biodegradability }\left(B_{d}\right) \% & =\frac{\text { Experimental methane yield }(E M Y)}{\text { Theoretical methane yield }(T M Y)} \times 100 \\
\text { Where TMY } & =\frac{22.4 \times 1000 \times\left(\frac{a}{2}+\frac{b}{8}-\frac{c}{4}-\frac{3 d}{8}\right)}{12 a+b+16 c+14 d}
\end{aligned}
$$

And $a, b, c \& d$ are subscripts for the empirical formula of substrate, i.e. $C_{a} H_{b} O_{c} N_{d}$ [42]

\section{Results}

\subsection{Biomass Composition of the Green Biorefinery Press Cake, Grass Whey and De-FOS Whey}

Feedstock analysis was performed for all the potential substrates (press cake, grass whey and de-FOS whey) derived from the greenbiorefinery for anaerobic digestion. The feedstock analysis involved proximate analysis (moisture and ash content), ultimate analysis (CHNOS, major and minor elements) and fiber content (Table 1). The moisture content in the press cake was found to be $61 \%$. Alternatively, grass whey and de-FOS whey being liquids had a high moisture content of $98 \%$ and $91 \%$, respectively. Meanwhile, the total solids accounted for $39 \%(w / w)$ of the press cake, $2.0 \%(w / w)$ for grass whey and $8.6 \%$ $(w / w)$ for de-FOS whey, respectively. The volatile solids and ash content analyses for both the wet and dry samples of the press cake revealed that $37 \%$ of the total composition of wet samples were contributed by volatile solids, while this number was $95 \%$ for dry samples. Conversely, the volatile solids and ash content in the grass whey was $79 \%$ and $21 \%$, respectively. Additionally, volatile solids and ash amounted to $6.9 \%$ and $80.1 \%$ of the 
total weight of de-FOS whey, respectively. The ratio of volatile solids to total solids is an important parameter in the efficiency of anaerobic digestion and methane production [43].

Elemental analysis was performed to determine the carbon, nitrogen, hydrogen and sulfur content in the press cake, grass whey and de-FOS whey. The C:N ratios for grass press cake and grass whey were found to be 17.4:1 and 19:1, while the C:N ratio for de-FOS whey was determined to be 9.3:1. The C/S ratios in the grass press cake, grass whey and de-FOS whey were found to be 207.2:1, 76:1 and 116:1, respectively. Meanwhile, the BOD and COD analysis of grass whey were conducted to determine the biodegradability of the feedstock. The BOD amounted to $798 \mathrm{~g} / \mathrm{kg}$ dry matter (DM), which amounted to $79 \%$ of the COD (968 g/ kg DM). This was similar for de-FOS whey, which had a BOD of $837 \mathrm{~g} / \mathrm{kg}$ DM and amounted to $85 \%$ of the measured COD of $984 \mathrm{~g} / \mathrm{kg}$ DM.

Potassium and sodium contents in the feedstocks were also measured as part of the elemental analysis. Detailed figures of the elemental analysis of the feedstocks have been provided in Tables 1 and 2. The concentration of potassium and sodium were found to be 5912 ppm and 928 ppm, as well as 6318 ppm and 238 ppm (fresh basis) for press cake and de-FOS whey, respectively. The phosphorus concentration of all biorefinery feedstocks, meanwhile, ranged between $150 \mathrm{ppm}$ and $900 \mathrm{ppm}$. At the same time, a trace elements analysis indicated that metals, such as iron, cobalt and molybdenum, were lower than required and would therefore need to be supplemented (Table 2).

Table 2. Concentration of trace elements in biorefinery feedstock.

\begin{tabular}{cccc}
\hline Analysis & Units & Grass Press Cake & De-FOS Whey \\
\hline Arsenic & ppm & $<1$ & - \\
Cadmium & ppm & $<1$ & $<1$ \\
Cobalt & ppm & 2 & $<1$ \\
Chromium & ppm & 41 & $<1$ \\
Copper & ppm & 10 & 10 \\
Mercury & ppm & 18 & $<1$ \\
Manganese & ppm & 35 & 169 \\
Molybdenum & ppm & 2 & 2 \\
Nickel & ppm & 54 & 8 \\
Lead & ppm & $<1$ & 3 \\
Antimony & ppm & $<1$ & $<1$ \\
Vanadium & ppm & $<1$ & $<1$ \\
Zinc & ppm & 47 & 88
\end{tabular}

All other values are reported on dry mass basis and followed reference method EN ISO 16968:2015 [30].

\subsection{Biogas and Biomethane Potential of Biorefinery Residual Co-Products (Grass Press Cake, De-FOS and Grass Whey)}

Assessment of the yield markers of the substrate samples, are presented in Table 3 and revealed that the biogas potential of grass whey and de-FOS whey, in particular, were quite promising. The biogas potential and biomethane potential of grass whey were found to be $895.8 \mathrm{~L} / \mathrm{kg}$ VS (707.7 L/kg VS) and $544 \mathrm{~L} / \mathrm{Kg}$ VS, respectively, although the substrate stream was diluted two-fold with wash water. Meanwhile, the biogas and biomethane potential of the de-FOS whey were found to be $597 \mathrm{~L} / \mathrm{Kg} \mathrm{VS}(478 \mathrm{~L} / \mathrm{Kg} \mathrm{DM})$ and $520 \mathrm{~L} / \mathrm{Kg}$ VS, respectively. The BMP analysis was performed on grass silage to compare the feedstocks with respect to their biogas and biomethane potential. Accordingly, grass silage yielded $479 \mathrm{~L} / \mathrm{Kg}$ VS of biogas and a biomethane potential of 300-700 L/Kg VS. The daily and cumulative biomethane yield for grass press cake, grass whey and de-FOS whey, as well as silage, from the BMP tests have been presented in Figure 2. 
Table 3. Biogas and biomethane summary data for grass press cake, whey and de-FOS whey.

\begin{tabular}{|c|c|c|c|c|c|c|}
\hline & & Grass Press Cake & Grass Whey & De-FOS Whey & Grass Silage & Dairy Whey \\
\hline $\begin{array}{c}\text { C:N ratio } \\
\text { Biogas and } \\
\text { biomethane } \\
\text { production }(\mathrm{L} / \mathrm{kg})\end{array}$ & $\begin{array}{l}\text { VS } \\
\text { DM } \\
\text { FM }\end{array}$ & $\begin{array}{c}19: 1 \\
510.7(300.3)^{*} \\
486.9(286.2)^{*} \\
189.9(111.6)^{*}\end{array}$ & $\begin{array}{c}17: 1 \\
895.8(544.6) * \\
707.7(430.3) * \\
14.3(8.7)^{*}\end{array}$ & $\begin{array}{c}9: 1 \\
597.4(520.3)^{*} \\
478.2(416.5)^{*} \\
41.5(36.1)^{*}\end{array}$ & $\begin{array}{c}17: 1 \\
808.1(479.0)^{*} \\
737.2(436.9)^{*} \\
132.9(78.8)^{*}\end{array}$ & $\begin{array}{c}- \\
(510-600) * \\
(280-330)^{*} \\
-\end{array}$ \\
\hline $\begin{array}{c}\text { Final weighted } \\
\text { biogas composition }\end{array}$ & $\begin{array}{c}\mathrm{CH}_{4}(\%) \\
\mathrm{CO}_{2}(\%) \\
\mathrm{O}_{2}(\%) \\
\mathrm{H}_{2} \mathrm{~S}(\mathrm{ppm}) \\
\mathrm{NH}_{3}(\mathrm{ppm})\end{array}$ & $\begin{array}{c}58.8 \\
43 \\
0.1 \\
17.6 \\
0\end{array}$ & $\begin{array}{l}60.8 \\
39.1 \\
0.2 \\
6.7 \\
3.7\end{array}$ & $\begin{array}{c}87.1 \\
14.8 \\
0 \\
87.7 \\
113.9\end{array}$ & $\begin{array}{c}59.3 \\
41.1 \\
0 \\
4.2 \\
0\end{array}$ & $\begin{array}{l}- \\
- \\
- \\
-\end{array}$ \\
\hline Biodegradability & $\%$ & 55 & 70 & 63 & - & - \\
\hline
\end{tabular}

* Biomethane yield markers for both feedstocks. Biomethane yield for dairy whey was referenced from [33].
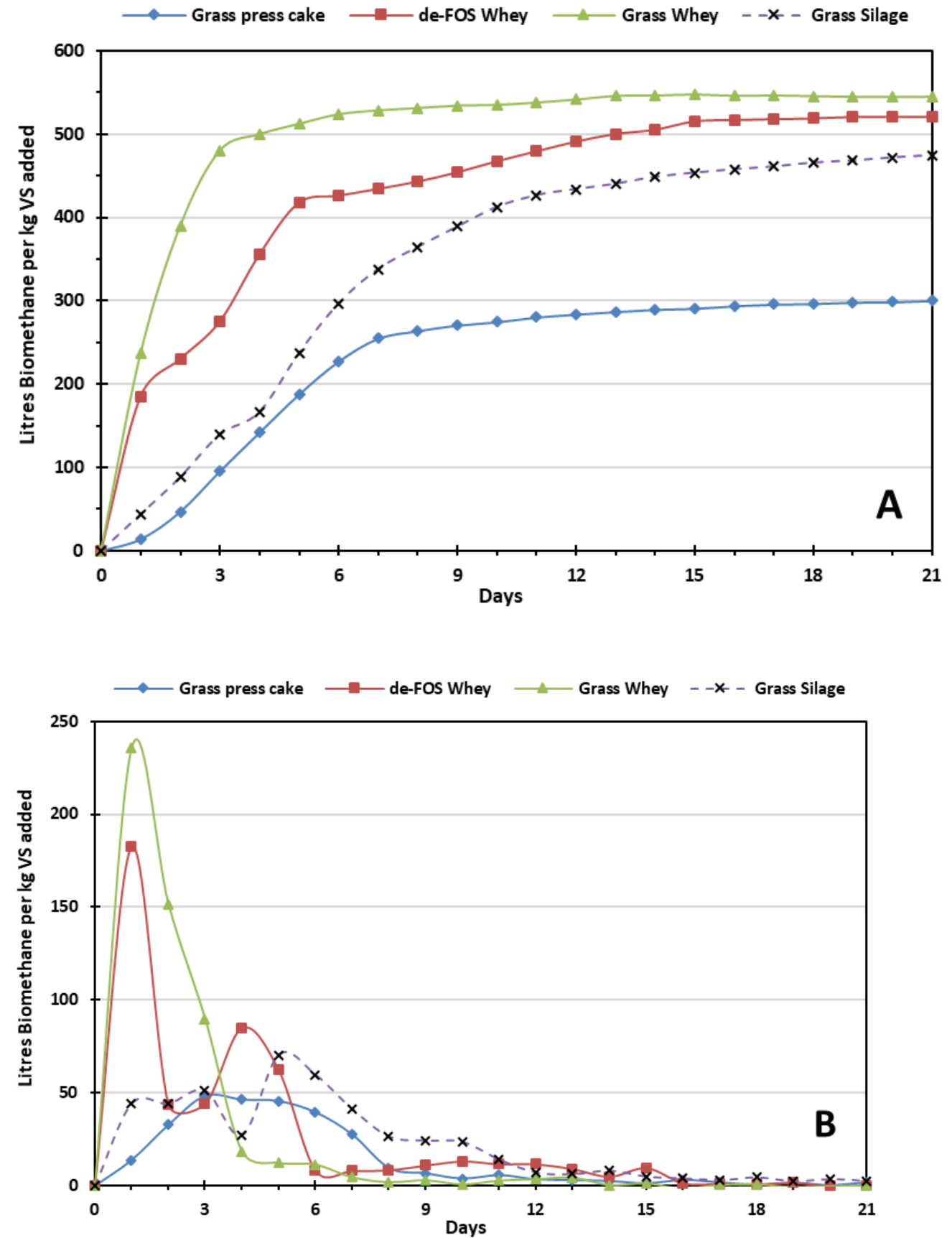

Figure 2. Cumulative (A) and daily (B) biomethane profiles for grass silage, grass press cake, whey and de-FOS whey. 


\subsection{Digestate Analysis to Determine the Fertilizer Potential of Biorefinery Residual Co-Products} after Anaerobic Digestion

The digestate samples from anaerobic digestion of the various biorefinery products were analyzed and characterized for their potential to serve as biofertilizers for improving grassland soil (Table 4). A comparison of Tables 1 and 4 indicated a high volatile solids (VS) destruction of $70 \%$ for grass whey, with a low of $43 \%$ and $45 \%$ VS destruction for de-FOS whey and grass press cake, respectively. This was bolstered by a digestate ultimate analysis, which showed that the carbon content reduction in grass whey was significantly higher than that of grass press cake and de-FOS whey. The carbon to nitrogen $(\mathrm{C}: \mathrm{N})$ ratio for all digestate samples was either 8:1 or 9:1. The CODs and BODs of the various digestate samples were lower than the pre-digestion substrates. Another key factor that influences the suitability of a digestate as a biofertilizer is the nitrogen to phosphorous to potassium (NPK) ratio. The NPK ratios for grass press cake, whey and de-FOS whey digestates were 2:1.6:1,1:1.8:3 and 1.4:1:2, changing significantly from their pre-digestion values.

Table 4. Digestate analysis for biorefinery products.

\begin{tabular}{ccccc}
\hline Analysis & Units & Grass Press Cake & Grass Whey & De-FOS Whey \\
\hline Moisture & $\%$ & $97.60^{*}$ & $98.99 *$ & $96.47^{*}$ \\
Total Solids & $\%$ & $2.40^{*}$ & $1.01^{*}$ & $3.53 *$ \\
Ash & $\%$ & 49.31 & 76.36 & 54.02 \\
Volatile Solids & $\%$ & 50.69 & 23.64 & 45.98 \\
C:N ratio & & $8: 1$ & $8: 1$ & $9: 1$ \\
NPK ratio & & $2: 1.6: 1$ & $1.4: 1: 2$ & $1: 1.8: 3$ \\
Carbon & $\%$ & 33.06 & 12.35 & 26.10 \\
Hydrogen & $\%$ & 3.88 & 1.66 & 4.31 \\
Nitrogen & $\%$ & 3.86 & 1.61 & 3.20 \\
Sulphur & $\%$ & 1.61 & 0.60 & 1.45 \\
Oxygen & $\%$ & 8.28 & 7.42 & 10.93 \\
Aluminium & $\mathrm{ppm}$ & 21,529 & & 22,851 \\
Calcium & $\mathrm{ppm}$ & 47,502 & & 56,109 \\
Iron & $\mathrm{ppm}$ & 30,548 & & 31,798 \\
Magnesium & $\mathrm{ppm}$ & 6065 & & 6277 \\
Sodium & $\mathrm{ppm}$ & 29,136 & 11,788 & 84,654 \\
Phosphorus & $\mathrm{ppm}$ & 31,838 & 23,339 & 101,207 \\
Potassium & $\mathrm{ppm}$ & 19,458 & & 16,729 \\
Silicon & $\mathrm{ppm}$ & 9106 & & 620 \\
Titanium & $\mathrm{ppm}$ & 383 & & 906 \\
COD & $\mathrm{g} / \mathrm{kg}$ & 833 & & 729 \\
BOD & $\mathrm{g} / \mathrm{kg}$ & 726 & & $1.57 *$ \\
Ammonia & $\mathrm{g} / \mathrm{kg}$ & $0.52 *$ & &
\end{tabular}

Note: * values reported on as-received basis. All other values are reported on dry mass basis.

\section{Discussion}

\subsection{Biomass Composition of the Green Biorefinery Press Cake, Grass Whey and De-FOS Whey}

As discussed in Section 3.1., whey and de-FOS whey had much higher moisture contents compared to press cake. The moisture content is important in the removal of volatile solids in an anaerobic digestion process because the removal of VS decreases significantly with a lower moisture content. The ratio of volatile solids to total solids is an important parameter in the efficiency of anaerobic digestion and methane production [44]. The analysis found that the total solids accounted for 39\% (w/w) of the press cake, $2.0 \%$ $(w / w)$ for grass whey and $8.6 \%(w / w)$ for de-FOS whey, while volatile solids made up $95 \%$ of dry matter for press cake, $79 \%$ for grass whey and $80 \%$ for de-FOS whey.

The C:N is critical for determining whether the feedstock is suitable for mono-digestion or co-digestion. A high $\mathrm{C}: \mathrm{N}$ ratio would result in the rapid consumption of nitrogen by acidogenic bacteria. Although this would positively affect the production of methane, the decrease in $\mathrm{pH}$ due to the accumulation of $\mathrm{NH} 4+$ ions would lead to low biogas production. 
The optimal C:N ratio in feedstocks for methanogenesis in anaerobic digestors falls in the range of 10 to 30 [45]. As outlined in Section 3.1, the C:N ratio of the press cake and grass whey indicate that they can form an excellent feedstock for mono-digestion in the presence of necessary trace elements. The C:N ratio for de-FOS whey was determined to be 9.3:1, indicating that although this feedstock is suitable for monodigestion, the adoption of a co-digestion strategy with another carbon rich feedstock to maintain the $\mathrm{C}: \mathrm{N}$ ratio within optimum range would be advantageous. Potentially suitable co-digestion feedstocks may include food waste and silage.

The presence of sulfur in biogas feedstocks has an adverse effect on the anaerobic digestion process due to the formation of $\mathrm{H}_{2} \mathrm{~S}$ which forms a constituent in the biogas produced. The recommended levels of $\mathrm{H}_{2} \mathrm{~S}$ in biogas must be lower than $100-500 \mathrm{mg} / \mathrm{Nm}^{3}$. According to a study conducted by Peu et al. (2015), the carbon to sulfur ratio should be a minimum of 40:1 for the $\mathrm{H}_{2} \mathrm{~S}$ levels to be maintained below $2 \%(v / v)$ in the biogas [46]. The C/S ratio in the grass press cake, grass whey and de-FOS, outlined in Section 3.1, were found to be within these recommend levels, suggesting that the risk of $\mathrm{H}_{2} \mathrm{~S}$ is considerably low. Meanwhile, the BOD and COD analysis of grass whey and de-FOS whey indicated that all the volatile solids present in both samples were biodegradable, further signifying the suitability of this feedstock for anaerobic digestion.

The concentration of potassium in a potential feedstock for anaerobic digestion should ideally be greater than that of sodium to neutralize the cell membrane potential. Furthermore, high concentrations of these ions could potentially disrupt the biogas production process. In a study involving desugared molasses for anaerobic digestion, Fang et al. (2011) reported a $50 \%$ inhibition of the biogas production process at sodium and potassium concentrations of $11,012.56$ and $28,032 \mathrm{ppm}$, respectively [47]. In the elemental analysis of the current study, the concentration of potassium and sodium in the press cake were found to be well below the inhibition concentrations. However, while the potassium levels were well below the inhibitory level when considering the dilution effect, the sodium concentration was found to be less than ideal. Furthermore, potassium levels were six times higher than that of sodium. A similar trend was observed for de-FOS whey, which had potassium and sodium levels of $6318 \mathrm{ppm}$ and $238 \mathrm{ppm}$, respectively, with potassium levels of 26 times that of sodium. Interestingly, the levels of potassium were below the range of the inhibitory level when considering the dilution effect in the anaerobic digestion process.

Phosphorus is a key nutrient in the anaerobic digestion process; however, higher levels of phosphorus can lead to eutrophication, which is undesirable. At high concentrations (>500 ppm), it may inhibit the anaerobic digestion process thus detrimentally affecting efficiency [48]. The phosphorus concentration of all biorefinery feedstocks ranged between $150 \mathrm{ppm}$ and $750 \mathrm{ppm}$. Therefore, considering the dilution effect in anaerobic digestion, the possibility of eutrophication and inhibitory effects of phosphorus can be eliminated in the digester.

\subsection{Biogas and Biomethane Potential of Biorefinery Residual Co-Products (Grass Press Cake, De-FOS and Grass Whey)}

Preliminary observations indicate that grass whey, de-FOS whey and grass press cake would not require pretreatment and should offer minimal process complications for biogas production. Although two and three separate products have been extracted from the whey and de-FOS whey, respectively, the biomethane potential of both residues were comparable to grass silage. In particular, grass whey showed quite good promise for biogas production, which may be enhanced with suitable co-digestion sources, as methane is a significant proportion of the overall gas volume, indicating that the biomethane potential of the feedstock is also significant. The biomethane potential of grass is also dependent on the cut of grass and harvesting stage [41].

Interestingly, the biomethane potential of de-FOS and grass whey were about $73 \%$ and $46 \%$ higher than that of grass press cake $(300 \mathrm{~L} / \mathrm{Kg} \mathrm{VS}, 286 \mathrm{~L} / \mathrm{Kg} \mathrm{DM})$ on a volatile solids and dry matter basis, respectively (Table 3). The higher biomethane potential of the liquid 
feedstocks regardless of the lower volatile solid content (about 80\% of DM as compared to press cake ( $95 \%$ of DM) may be attributed to the easily digestible solubilized components in both whey samples $[49,50]$. These solubilized components most likely account for a greater proportion of the $984 \mathrm{~g} / \mathrm{Kg}$ COD measured for the whey. This is probably not the case with grass press cake, with the majority of its volatile solids content and the COD $(1143 \mathrm{~g} / \mathrm{Kg})$ composed of complex components such as cellulose, hemicellulose, lignin and crude fiber. Interestingly, the biomethane potential of de-FOS and grass whey was similar to the dairy whey feedstock, which is reported to be 500 to $600 \mathrm{~L} / \mathrm{Kg}$ VS on average (Table 3) [44]. This is encouraging, especially for de-FOS whey, since this feedstock was devoid of polysaccharides and proteins, as compared to dairy whey, which has high concentrations of disaccharide, lactose and protein [51]. A further observation of Figure 2 indicated that a short retention time below 5 days was able to produce $80 \%$ of the total biogas potential from both de-FOS and grass whey. The biogas productivities of grass whey and de-FOS whey were significantly better than grass silage which generally takes at least 12-20 days to yield such biogas productivity.

Methane on average accounted for $87 \%$ of total biogas produced from the de-FOS whey. De-FOS whey had excellent yield markers considering the BMP analysis of press grass cake and grass whey, yielding a weighted average methane content of $59 \%$. However, the biomethane potential of de-FOS whey $(36 \mathrm{~L} / \mathrm{Kg} \mathrm{FM})$, as well as grass whey $(8.7 \mathrm{~L} / \mathrm{Kg}$ FM), on fresh matter basis was $68-93 \%$ lesser than that of grass press cake $(112 \mathrm{~L} / \mathrm{Kg}$ FM). This may be due to the high moisture contents of both whey substrates as compared to that of grass press cake (Table 1). Meanwhile, the high COD content of de-FOS and grass whey along with their shorter retention times for maximum biomethane production are desirable, as they are directly related to a reduction in capital cost and the increase in process efficiency. While an initial analysis indicates that most of the biogas could be produced within a number of days, this could feasibly decrease to a number of hours depending on the AD system, especially if high-rate digesters such as up flow anaerobic sludge blanket (UASB) and the induced blanket reactor (IBR) digesters are used for the digestion process [52].

Elemental analysis performed on grass press cake indicated a substrate with a good C:N ratio suitable for mono-digestion (Table 1 ). The biodegradability of grass press cake was lower (55\%) than grass whey (63\%). Regardless, grass press cake showed significant potential by achieving $80 \%$ of the total biogas after 7-10 days of digestion (Figure 2). Additionally, biomethane production from grass press cake achieved an efficiency of $71 \%$ based on predicted total methane from the COD analysis. Although this was lower than the efficiency of whey, the biodegradability index in terms of BOD5 to the COD ratio of 0.8 for grass press cake indicated that the majority of the sample was still biodegradable. Furthermore, on wet basis, the biomethane and biogas potential of grass press cake of $112 \mathrm{~L} / \mathrm{Kg}$ and $190 \mathrm{~L} / \mathrm{Kg}$, respectively, were 3.1 and 4.5 times that of de-FOS whey (Table 3). With a biogas potential of $517 \mathrm{~L} / \mathrm{Kg}$ VS and a biomethane potential of $304 \mathrm{~L} / \mathrm{Kg} \mathrm{VS}$, the performance of grass press cake is about 37\% less than that of grass silage (Table 3 ). Interestingly, fresh-basis biomethane yield from grass press cake was 30\% higher than grass silage, making it a very interesting feedstock for biogas or biomethane production.

\subsection{Digestate Analysis to Determine the Fertilizer Potential of Biorefinery Residual Co-Products after Anaerobic Digestion}

The carbon to nitrogen $(\mathrm{C}: \mathrm{N})$ ratio for all digestate samples from digested biorefinery by-products was either $8: 1$ or $9: 1$ and was similar to that of soil organic matter (8:1 to 12:1) [53-55]. A higher C:N causes the depletion of nitrogen in the soil, as microorganisms strip the nitrogen from the soil to break down and assimilate carbon (microbial immobilization) [56]. However, the low $\mathrm{C}: \mathrm{N}$ ratios observed for the various digestate samples indicated their suitability as fertilizer in terms of $\mathrm{C}: \mathrm{N}$ ratio, as there is rapid mineralization and release of nitrogen in the soil for plant uptake [56]. In addition to the C:N ratio, the digestate BOD and biodegradability are two other factors considered to be key in affecting 
the aerobic decomposition of organic matter in soil [57]. The CODs and BODs of the various digestate samples were lower than the pre-digestion substrates. The corresponding biodegradability index ranged within 0.80 and 0.87 , indicating that the digestate samples were easily biodegradable under aerobic conditions in the presence of a suitable consortium bacteria, such as activated sludge [58].

The NPK for grass press cake digestate changed significantly with the anaerobic digestion (2:1.6:1) and was closer to the recommended NPK fertilizer concentration of 3:1:1 when compared to the other digestate samples resulting from digested grass whey and de-FOS whey [59]. The NPK for de-FOS whey digestate also changed significantly following anaerobic digestion (shifting from 4.3:1:7.3 to 1:1.8:3); however, the digestate NPK fell considerably below the recommended fertilizer NPK concentration of 3:1:1. A similar NPK ratio of 1.4:1:2 was also evaluated for grass whey digestate. Hence, both the de-FOS and grass whey digestate samples did not qualify to be used directly as organic fertilizer. However, due to their high potassium concentration, there is potential for them to be converted to potassium-rich fertilizer for potassium deficient soils. From the nitrogen, phosphorus and potassium levels, it was evident that the pre-digestion biorefinery substrates were not suitable for direct fertilizer use considering that their NPK ratios were beyond the recommended biofertilizer range of 3:1:1 (Table 1).

\section{Conclusions}

The paper has investigated and discussed the biogas and biomethane potential of three processing co-products and sidestreams resulting from a green biorefinery process based on perennial ryegrass as feedstock, namely press cake, whey and de-FOS whey. The analysis, taking into account key parameters such as the $C: N$ ratio, $C / S$ ratio, biodegradability of volatile solids, potassium and phosphorous levels, indicates that all three feedstocks are of suitable composition for use in anerobic digestion, including for mono-digestion. Grass whey and de-FOS whey yielded the highest biogas productivity with $895.8 \mathrm{~L} / \mathrm{kg}$ VS and $597.4 \mathrm{~L} / \mathrm{kg}$ VS, respectively. This was followed by press cake $(510.7 \mathrm{~L} / \mathrm{kg} \mathrm{VS})$. Meanwhile, de-FOS whey provided the highest overall yields of biomethane at $87 \%$ of total biogas. From the digestate analysis, it was clear that a large fraction of the volatile solids in the grass whey was consumed within the digestion process, justifying the high biogas production yield. Furthermore, the C:N ratio of all the feedstocks fell within the range of soil organic matter. However, only press cake digestate qualified as a potential fertilizer due to the NPK ratio falling within the recommended range. As for the grass whey and de-FOS whey digestates, the potassium content was found to be too high, beyond the recommended range, rendering them unsuitable as soil fertilizer. Further research is recommended to enhance nutrient concentration in the digestate by modifying the AD configuration to render them more suitable for agricultural purposes. Future research may also explore the further benefits of integrating green biorefinery with biogas production, including quantifying the environmental benefits of utilising residual heat and electricity from the AD system to meet the energy requirements of the process.

Author Contributions: Conceptualization, J.G., R.R., H.M., J.P.M.S., S.K. and L.G.; methodology, J.G., R.R., H.M., J.P.M.S., S.K. and L.G.; investigation; J.G., R.R., H.M., J.P.M.S., S.K. and L.G., writingoriginal draft preparation, J.G., R.R., L.G. and K.D., writing-review and editing, J.G., R.R., H.M., J.P.M.S., S.K., L.G., K.D., A.M. and A.J.G.; funding acquisition, J.G. All authors have read and agreed to the published version of the manuscript.

Funding: The research was conducted during the Biorefinery Glas project funded by Ireland's Department of Agriculture, Food and the Marine (DAFM) and EIP-AGRI (Contract no: LLOC2043).

Institutional Review Board Statement: Not applicable.

Informed Consent Statement: Not applicable.

Data Availability Statement: Not applicable. 


\begin{abstract}
Acknowledgments: The authors would like to acknowledge the funding provided by the DAFM and EIP-AGRI. The authors would also like to acknowledge the Carbery farmers and Carbery Group team who participated in the Biorefinery demonstration activities, as well as our partners at University College Dublin and Barryroe Cooperative who contributed significantly to the project.
\end{abstract}

Conflicts of Interest: The authors declare no conflict of interest.

\title{
References
}

1. Mann, M.E. Radical reform and the Green New Deal. Nat. Cell Biol. 2019, 573, 340-341. [CrossRef]

2. European Parliament. Directive 2009/28/EC of the European Parliament and of the Council of 23 April 2009 on the Promotion of the Use of Energy from Renewable Sources and Amending and Subsequently Repealing Directives 2001/77/EC and 2003/30/EC. Available online: https: / / eur-lex.europa.eu/legal-content/EN/ALL/?uri=CELEX\%3A32009L0028 (accessed on 16 August 2021).

3. Holland, M.H.D.D.M. (Ed.) Renewable Energy in Ireland, S.E.A.o. Ireland. Available online: https://www.seai.ie/publications/ 2020-Renewable-Energy-in-Ireland-Report.pdf (accessed on 13 August 2021).

4. O'Neill, A. Ireland: Distribution of Gross Domestic Product (GDP) Across Economic Sectors from 2010 to 2020. 2021, Statista. Available online: https:/ / www.statista.com/statistics/375575/ireland-gdp-distribution-across-economic-sectors/ (accessed on 16 August 2021).

5. Agriculture and Food Development Authority. Agricultural Emissions-Greenhouse Gases and Ammonia. In Virtual Beef Week. Available online: https:/ / www.teagasc.ie/publications/2020/agricultural-emissions-greenhouse-gases-and-ammonia. php (accessed on 16 August 2021).

6. Walther, C.A.; García, C.; Dwyer, N.; Gault, J. Climate Status Report for Ireland. Available online: https://www.epa.ie/ publications/research/climate-change/Research_Report_386.pdf (accessed on 13 August 2021).

7. Díaz-Vázquez, D.; Alvarado-Cummings, S.C.; Meza-Rodríguez, D.; Senés-Guerrero, C.; de Anda, J.; Gradilla-Hernández, M.S. Evaluation of Biogas Potential from Livestock Manures and Multicriteria Site Selection for Centralized Anaerobic Di-gester Systems: The Case of Jalisco, México. Sustainability 2020, 12, 3527. [CrossRef]

8. Association, E.B. About Biogas and Biomethane. 2021, European Biogas Association. Available online: https://www. europeanbiogas.eu/about-biogas-and-biomethane (accessed on 16 August 2021).

9. Central Statistics Office Ireland. Farm Structure Survey 2013. Available online: https://www.cso.ie/en/methods/ agricultureandfishing/farmstructuresurvey/ (accessed on 13 August 2021).

10. Biernacki, P.; Steinigeweg, S.; Borchert, A.; Uhlenhut, F. Application of Anaerobic Digestion Model No. 1 for describing anaerobic digestion of grass, maize, green weed silage, and industrial glycerine. Bioresour. Technol. 2013, 127, 188-194. [CrossRef]

11. Lehtomäki, A.; Huttunen, S.; Lehtinen, T.; Rintala, J. Anaerobic digestion of grass silage in batch leach bed processes for methane production. Bioresour. Technol. 2008, 99, 3267-3278. [CrossRef] [PubMed]

12. McEniry, J.; Allen, E.; Murphy, J.; O'Kiely, P. Grass for biogas production: The impact of silage fermentation charac-teristics on methane yield in two contrasting biomethane potential test systems. Renew. Energy. 2014, 63, 524-530. [CrossRef]

13. Wall, D.M.; Allen, E.; Straccialini, B.; O'Kiely, P.; Murphy, J.D. Optimisation of digester performance with increasing organic loading rate for mono- and co-digestion of grass silage and dairy slurry. Bioresour. Technol. 2014, 173, 422-428. [CrossRef]

14. Attard, J.; McMahon, H.; Doody, P.; Belfrage, J.; Clark, C.; Anda Ugarte, J.; Pérez-Camacho, M.N.; Cuenca Martín, M.d.S.; Giráldez Morales, A.J.; Gaffey, J. Mapping and Analysis of Biomass Supply Chains in Andalusia and the Republic of Ireland. Sustainability 2020, 12, 4595. [CrossRef]

15. McEniry, J.; Crosson, P.; Finneran, E.; McGee, M.; Keady, T.; O’Kiely, P. How much grassland biomass is available in Ireland in excess of livestock requirements? Ir. J. Agric. Food Res. 2013, 68, 67-80.

16. Xie, S. Evaluation of Biogas Production from Anaerobic Digestion of Pig Manure and Grass Silage. Available online: http: / / hdl.handle.net/10379/3023 (accessed on 23 August 2021).

17. Himanshu, H.; Murphy, J.D.; Lenehan, J.J.; O'Kiely, P. Impacts of characteristics of grass silage and cattle slurry feedstocks on the cost of methane production. Biofuels Bioprod. Biorefining 2018, 13, 129-139. [CrossRef]

18. Beausang, C.; McDonnell, K.; Murphy, F. Assessing the environmental sustainability of grass silage and cattle slurry for biogas production. J. Clean. Prod. 2021, 298, 126838. [CrossRef]

19. Gas Networks Ireland. The Future of Renewable Gas in Ireland. 2021. Available online: https://www.gasnetworks.ie/corporate/ company/our-commitment/environment/renewable-gas/ (accessed on 13 August 2021).

20. Alagarsamy, A. Ervia-Decarbonising Domestic Heating in Ireland. Available online: http://www.ervia.ie/decarbonisingdomestic-he/ (accessed on 16 August 2021).

21. O'Connor, S.; Ehimen, E.; Pillai, S.C.; Power, N.; Lyons, G.A.; Bartlett, J. An Investigation of the Potential Adoption of Anaerobic Digestion for Energy Production in Irish Farms. Environments 2021, 8, 8. [CrossRef]

22. Xiu, S.; Shahbazi, A. Development of Green Biorefinery for Biomass Utilization: A Review. Trends Renew. Energy 2015, 1, 4-15. [CrossRef]

23. Schwinn, V. Biowert Grass Biorefinery. Available online: https://www.ieabioenergy.com/blog/publications/new-publicationbiowert-grass-biorefinery-biobased-plastics-germany/ (accessed on 13 August 2021). 
24. Stødkilde, L.; Ambye-Jensen, M.; Jensen, S.K. Biorefined organic grass-clover protein concentrate for growing pigs: Effect on growth performance and meat fatty acid profile. Anim. Feed. Sci. Technol. 2021, 276, 114943. [CrossRef]

25. Fonseca, L.M.; Domingues, J.P.; Dima, A.M. Mapping the Sustainable Development Goals Relationships. Sustainability 2020, 12, 3359. [CrossRef]

26. Santamaría-Fernández, M.; Molinuevo-Salces, B.; Lübeck, M.; Uellendahl, H. Biogas potential of green biomass after protein extraction in an organic biorefinery concept for feed, fuel and fertilizer production. Renew. Energy 2018, 129, 769-775. [CrossRef]

27. Feng, L.; Ward, A.J.; Ambye-Jensen, M.; Møller, H.B. Pilot-scale anaerobic digestion of by-product liquid (brown juice) from grass protein extraction using an un-heated anaerobic filter. Process. Saf. Environ. Prot. 2021, 146, 886-892. [CrossRef]

28. Patterson, T.; Massanet-Nicolau, J.; Jones, R.; Boldrin, A.; Valentino, F.; Dinsdale, R.; Guwy, A. Utilizing grass for the biological production of polyhydroxyalkanoates (PHAs) via green biorefining: Material and energy flows. J. Ind. Ecol. 2021, 25, 802-815. [CrossRef]

29. Souza, M.F.; Devriendt, N.; Willems, B.; Guisson, R.; Biswas, J.K.; Meers, E. Techno-economic Feasibility of Extrusion as a Pretreatment Step for Biogas Production from Grass. BioEnergy Res. 2021, 1-8. [CrossRef]

30. Feeney, F.; Buckley, E.; Gaffey, J.; Hayes, D.; Gottumukkala, L. Report on the Potential of Recirculated Grass Whey as a Nutrient Fertilizer and Opportunities for Grass Whey in Biogas Production. Biorefinery Glas Project. Available online: https: //biorefineryglas.eu/wp-content/uploads/2021/03/Biorefinery-Glas-D2.6.pdf (accessed on 1 December 2021).

31. Wall, D.M. Biomethane Production from Grass Silage: Laboratory Assessment to Maximise Yields. UCC. Available online: https:/ / cora.ucc.ie/handle/10468/2103 (accessed on 1 December 2021).

32. Murphy, J.D.; Korres, N.E.; Singh, A.; Smyth, B.; Nizami, A.; Thamsiriroj, T. The Potential for Grass Biomethane as a Biofuel: Compressed Biomethane Generated from Grass, Utilized as a Transport Biofuel. EPA. Available online: https:// www.epa.ie/publications/research/climate-change/CCRP11-The-Potential-for-Grass-Biomethane-as-a-Biofuel.pdf (accessed on 1 December 2021).

33. Wall, D.M.; O'Kiely, P.; Murphy, J.D. The potential for biomethane from grass and slurry to satisfy renewable energy targets. Bioresour. Technol. 2013, 149, 425-431. [CrossRef]

34. Corona, A.; Ambye-Jensen, M.; Vega, G.C.; Hauschild, M.Z.; Birkved, M. Techno-environmental assessment of the green biorefinery concept: Combining process simulation and life cycle assessment at an early design stage. Sci. Total Environ. 2018, 635, 100-111. [CrossRef]

35. Hermansen, J.E.; Jorgenson, U.; Laerke, P.E.; Manevski, K.; Boelt, B.; Jensen, S.K.; Weisbjerg, M.; Daalsgaard, T.K.; Danielsen, M.; Asp, T.; et al. Green Biomass Protein Production through Biorefining. Aarhus University. Available online: https://pure.au.dk/ portal/files/110736531/DCArapport093.pdf (accessed on 1 December 2021).

36. Sluiter, A.; Hames, B.; Ruiz, R.; Scarlata, C.; Sluiter, J.; Templeton, D.; Crocker, D. Determination of structural carbohydrates and lignin in biomass. Lab. Anal. Proced. 2008, 1617, 1-16.

37. ISO 16994:2015; Solid Biofuels-Determination of Total Content of Sulfur and Chlorine. NIST: Gaithersburg, MA, USA, 2015.

38. EN, B. 2011; Determination of Major Elements-Al, Ca, Fe, Mg, P., K., Si, Na and Ti. British Standards Institution: London, UK, 2011.

39. O'Dell, J. The Determination of Chemical Oxygen Demand by SEMI-Automated Colorimetry-Method 410; Environmental Monitoring Systems Laboratory: Cincinnati, OH, USA; Office of Research and Development, US Environmental Protection Agency: Washington, DC, USA, 1993.

40. ISO/TC 238, S.b. 2015b; Solid Biofuels-Determination of Minor Elements. NIST: Gaithersburg, MA, USA, 2015.

41. Prochnow, A.; Heiermann, M.; Drenckhan, A.; Schelle, H. Seasonal pattern of biomethanisation of grass from landscape management. Int. J. Agric. Eng. 2005, 7, 1-17.

42. Li, J.; Zhang, R.; Siddhu, M.A.H.; He, Y.; Wang, W.; Li, Y.; Chen, C.; Liu, G. Enhancing methane production of corn stover through a novel way: Sequent pretreatment of potassium hydroxide and steam explosion. Bioresour. Technol. 2015, 181, 345-350. [CrossRef] [PubMed]

43. Wang, X.; Duan, X.; Chen, J.; Fang, K.; Feng, L.; Yan, Y.; Zhou, Q. Enhancing anaerobic digestion of waste activated sludge by pretreatment: Effect of volatile to total solids. Environ. Technol. 2016, 37, 1520-1529. [CrossRef]

44. Escalante, H.; Castro, L.; Amaya, M.P.; Jaimes, L.; Jaimes-Estévez, J. Anaerobic digestion of cheese whey: Energetic and nutritional potential for the dairy sector in developing countries. Waste Manag. 2018, 71, 711-718. [CrossRef]

45. Yan, Z.; Song, Z.; Li, D.; Yuan, Y.; Liu, X.; Zheng, T. The effects of initial substrate concentration, C/N ratio, and tem-perature on solid-state anaerobic digestion from composting rice straw. Bioresour. Technol. 2015, 177, 266-273. [CrossRef]

46. Peu, P.; Picard, S.; Diara, A.; Girault, R.; Béline, F.; Bridoux, G.; Dabert, P. Prediction of hydrogen sulphide production during anaerobic digestion of organic substrates. Bioresour. Technol. 2012, 121, 419-424. [CrossRef]

47. Fang, C.; Boe, K.; Angelidaki, I. Anaerobic co-digestion of desugared molasses with cow manure; focusing on sodium and potassium inhibition. Bioresour. Technol. 2011, 102, 1005-1011. [CrossRef] [PubMed]

48. Mancipe-Jiménez, D.C.; Costa, C.; Márquez, M.C. Methanogenesis inhibition by phosphorus in anaerobic liquid waste treatment. Waste Treat. Recover. 2017, 2, 1-8. [CrossRef]

49. Donkor, K.O.; Gottumukkala, L.D.; Diedericks, D.; Görgens, J.F. An advanced approach towards sustainable paper industries through simultaneous recovery of energy and trapped water from paper sludge. J. Environ. Chem. Eng. 2021, 9, 105471. [CrossRef] 
50. Liu, Y.; Xu, J.; Zhang, Y.; Yuan, Z.; He, M.; Liang, C.; Zhuang, X.; Xie, J. Sequential bioethanol and biogas production from sugarcane bagasse based on high solids fed-batch SSF. Energy 2015, 90, 1199-1205. [CrossRef]

51. Waldron, K.W. Handbook of Waste Management and Co-Product Recovery in Food Processing; Woodhead Publishing: Sawston, UK, 2009.

52. Vertes, A.A.; Qureshi, N.; Yukawa, H.; Blaschek, H.P. Biomass to Biofuels: Strategies for Global Industries, 1st ed.; John Wiley \& Sons: Hoboken, NJ, USA, 2011.

53. Boyd, C.E. Carbon: Nitrogen Ratio Management. Global Aquaculture Advocate. Available online: https://www. aquaculturealliance.org/advocate/carbon-nitrogen-ratio-management/ (accessed on 16 August 2021).

54. Clapp, C.E.; Hayes, M.H.B.; Simpson, A.J.; Kingery, W.L. Chemistry of Soil Organic Matter. In SSSA Book Series; John Wiley\&Sons: Hoboken, NJ, USA, 2018; pp. 1-150.

55. Liang, C.; Balser, T.C. Microbial production of recalcitrant organic matter in global soils: Implications for productivity and climate policy. Nat. Rev. Genet. 2010, 9, 75. [CrossRef] [PubMed]

56. Brust, G.E. Management strategies for organic vegetable fertility. In Safety and Practice for Organic Food; Biswas, D., Shirley, A.M., Eds.; Elsevier: Amsterdam, The Netherlands, 2019; pp. 193-212.

57. Möller, K.; Müller, T. Effects of anaerobic digestion on digestate nutrient availability and crop growth: A review. Eng. Life Sci. 2012, 12, 242-257. [CrossRef]

58. Baraza, X.; Sáez-Navarrete, C.; Torres-Castillo, R. Anaerobic biodegradability of leachate from MSW intermediate landfill. Afinidad 2019, 76, 585.

59. Zhang, M.; Wang, Z.; Zhang, X.; Qian, X.; Shen, G. Biogas and quality fertilizer production from dry anaerobic digestion of rice straw with nitrogen addition. Bioresour. Technol. Rep. 2020, 11, 100509. [CrossRef] 